\title{
Brazing of 422 stainless steel using the AWS classification BNi-2 Braze alloy
}

\author{
C. L. Ou $\cdot$ D. W. Liaw $\cdot$ Y. C. Du $\cdot$ R. K. Shiue
}

Received: 29 August 2003/ Accepted: 25 July 2005/Published online: 12 August 2006

(C) Springer Science+Business Media, LLC 2006

\begin{abstract}
The study of brazing 422 stainless steel (422SS) using the AWS classification BNi-2 braze alloy as the filler metal is evaluated in the study. The $\mathrm{BNi}-2$ braze alloy demonstrates excellent wettability on the 422SS substrate for temperatures exceeding $1025^{\circ} \mathrm{C}$. The brazed joint is primarily comprised of the Ni-rich matrix and chromium boride. Additionally, the B-CrFe precipitates are formed at the interface between the braze and 422SS. Some Kirkendall porosity is also observed in the braze close to the interface, due to nonsymmetrical interdiffusion between the braze and 422SS substrate. Shear strengths of brazed joints are varied from 306 to $481 \mathrm{MPa}$. The infrared brazed specimen shows the highest shear strength among all brazed specimens. Increasing brazing temperature and/ or time result in decreased shear strength of the brazed joint.
\end{abstract}

\section{Introduction}

The 422 stainless steel (422SS) is featured with good corrosion resistance, oxidation resistance and moderate creep strength, so it is widely applied in highpressure steam turbine blades [1-4]. The 422SS is a

C. L. Ou · D. W. Liaw · Y. C. Du

Department of Materials Science and Engineering, National Dong Hwa University, Hualien 974, Taiwan

R. K. Shiue $(\bowtie)$

Department of Materials Science and Engineering, National Taiwan University, Taipei 106, Taiwan

e-mail: rkshiue@ntu.edu.tw type of martensitic stainless steel, and its nominal composition in weight percent is $(0.2-0.25) \mathrm{C}, 1.0 \mathrm{Mn}$, 1.0Si (max.), (0.5-1.0)Ni, (11.5-13.5)Cr, (0.75-1.25)Mo, $(0.2-0.5) \mathrm{V},(0.75-1.25) \mathrm{W}$ and balance Fe [5-8]. Because the 422SS contains many alloying elements, such as $\mathrm{Cr}, \mathrm{Mo}, \mathrm{V}, \mathrm{W}$... etc, it is difficult to repair with welding based processes due to the high hardenability of the steel. Repair brazing is one of the alternative methods to fix shallow cracks on the turbine blade [912]. The successful brazing of 422SS using the AWS classification $\mathrm{BNi}-3$ braze alloy was performed in a previous study [13]. Compared with the $\mathrm{BNi}-3$ braze alloy, the $\mathrm{BNi}-2$ braze alloy has lower solidus/liquidus temperatures, which are beneficial in brazing 422SS. Additionally, it is also expected that the corrosion resistance of $\mathrm{BNi}-2$ braze alloy is better than that of $\mathrm{BNi}-3$ braze alloy due to the additional $7 \mathrm{wt} \% \mathrm{Cr}$ in the $\mathrm{BNi}-2$ braze alloy [9].

Infrared heating is a novel technique featured with extraordinary high heating rate up to $3000^{\circ} \mathrm{C} / \mathrm{min}$, and it has been successfully applied in brazing various materials [12, 14-17]. The application of infrared heating in brazing is very important for the filler metal with a wide melting range, since a fast brazing thermal cycle is necessary in order to avoid liquation of the braze alloy $[10,11]$. Additionally, the growth of brittle interfacial reaction layer(s) between the base metal and braze alloy can be greatly inhibited by using a rapid thermal cycle. Consequently, a fast brazing cycle is beneficial to practical applications.

The purpose of this investigation is to study the repair brazing of 422SS. A nickel base braze alloy, $\mathrm{BNi}-2$, is used as the filler metal. Both the traditional furnace brazing and infrared brazing are performed in the experiment. The microstructural evolution and 
shear strength of the brazed joint are extensively evaluated.

\section{Experimental procedures}

The base metal used in the experiment was 422SS, and its chemical composition in weight percent was $0.24 \mathrm{C}$, $0.71 \mathrm{Mn}, \quad 0.38 \mathrm{Si}, \quad 0.016 \mathrm{P}, \quad 0.006 \mathrm{~S}, \quad 0.76 \mathrm{Ni}, \quad 11.98 \mathrm{Cr}$, $1.07 \mathrm{Mo}, 0.26 \mathrm{~V}, 0.99 \mathrm{~W}$ and balance Fe. A nickel base filler metal, Nicrobraz ${ }^{\circledR}$ LM purchased from Wall Colmonoy Corporation, was applied in brazing 422SS, and its chemical composition in weight percent was 7.0 $\mathrm{Cr}, 3.1 \mathrm{~B}, 4.5 \mathrm{Si}, 3.0 \mathrm{Fe}$, and $\mathrm{Ni}$ balance. According to the AWS specification for the nickel base braze alloys, the chemical composition of Nicrobraz ${ }^{\circledR}$ LM alloy was consistent with the BNi-2 braze alloy [9-11]. The filler metal was in the form of foils with the thickness of $50 \mu \mathrm{m}$ and $152.4 \mathrm{~mm}$ wide.

Dynamic wetting angle measurements were made using the traditional furnace at the temperature range between $1025{ }^{\circ} \mathrm{C}$ and $1100{ }^{\circ} \mathrm{C}$ for $0-1800 \mathrm{~s}$ [13, 18]. The $0.15 \mathrm{~g}$ spherical ball prepared by vacuum arc remelting (VAR) Nicrobraz ${ }^{\circledR}$ LM foil was placed on the 422SS substrate, and heating rate of the furnace was set at $30{ }^{\circ} \mathrm{C} / \mathrm{min}$ throughout the experiment. The image of wetting angle was recorded using an Olympus C-5050 digital camera during the wetting angle measurement.

Infrared brazing was performed in a vacuum of $5 \times 10^{-5}$ mbar at $1050{ }^{\circ} \mathrm{C}$ for 60,180 and $300 \mathrm{~s}$, respectively. The heating rate of the infrared furnace was set at $600{ }^{\circ} \mathrm{C} / \mathrm{min}$, and the sample was preheated at $600{ }^{\circ} \mathrm{C}$ for $600 \mathrm{~s}$ prior to the brazing temperature. Traditional furnace brazing was performed in a

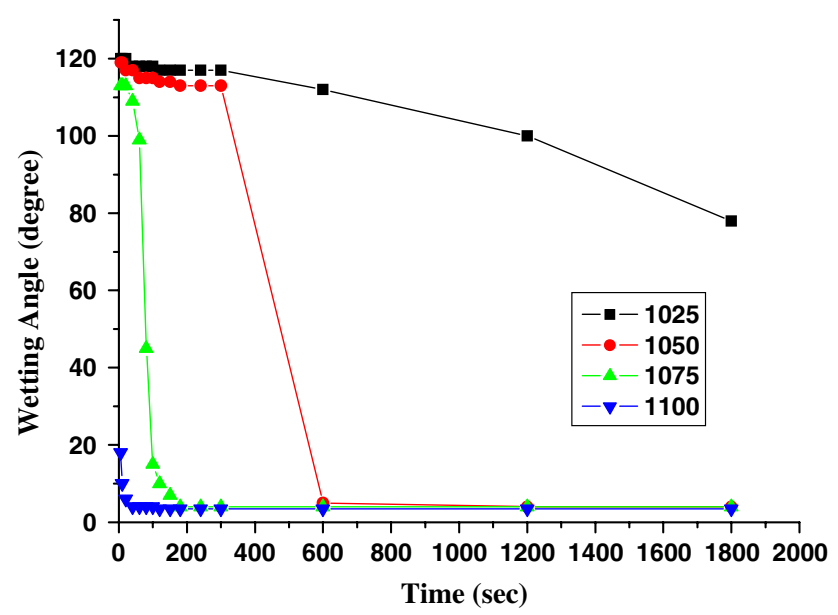

Fig. 1 The wetting angle measurements of $\mathrm{BNi}-2$ braze alloy on 422SS for $1025-1100{ }^{\circ} \mathrm{C}$ vacuum of $5 \times 10^{-5} \mathrm{mbar}$ at 1050,1075 and $1100{ }^{\circ} \mathrm{C}$ for various time periods. The heating rate of furnace brazing was set at $30^{\circ} \mathrm{C} / \mathrm{min}$ throughout the experiment. Similarly, samples were preheated at $600{ }^{\circ} \mathrm{C}$ for $600 \mathrm{~s}$ prior to the brazing temperature. The furnacebrazed specimen was subsequently heat-treated at
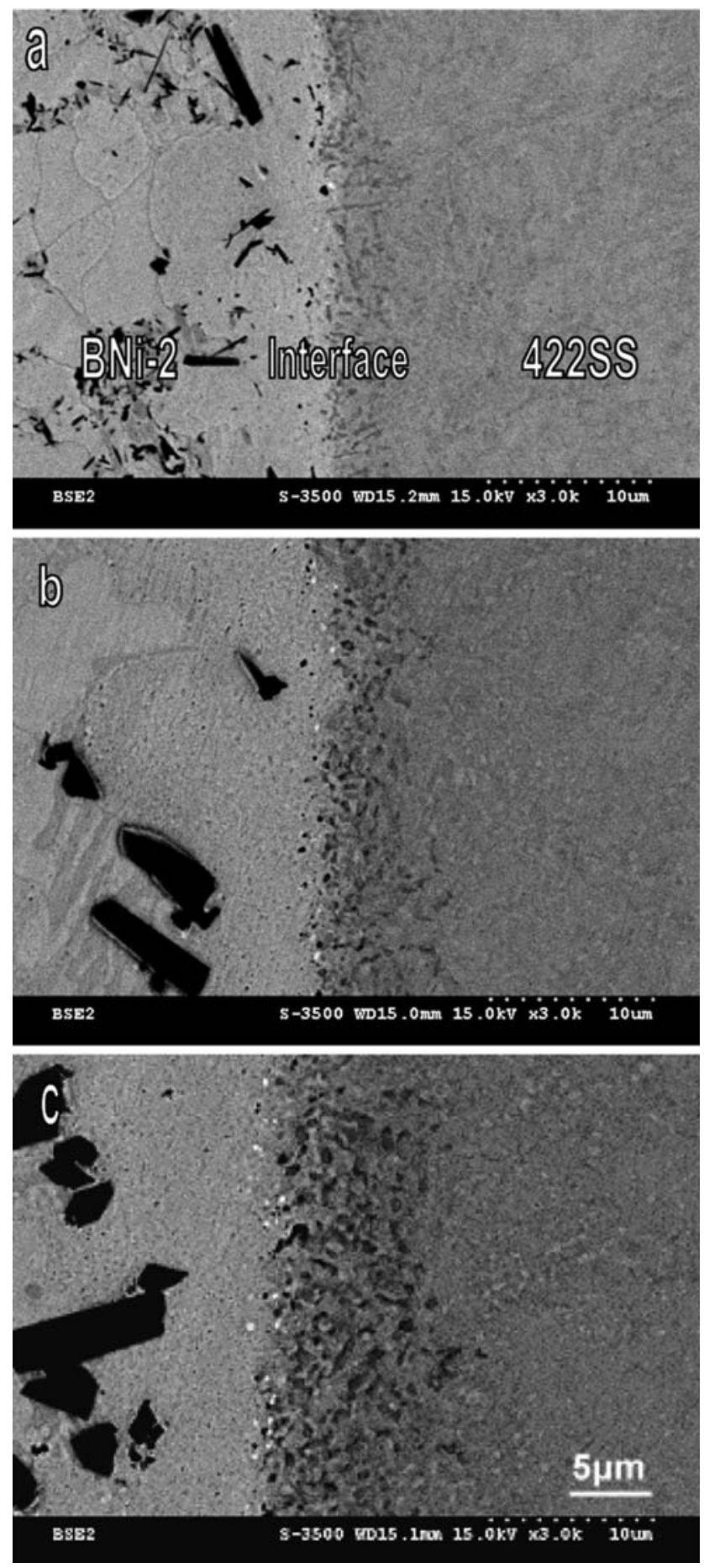

Fig. 2 The SEM BEIs of infrared brazed specimens at $1050{ }^{\circ} \mathrm{C}$ for (a) 60, (b) 180 and (c) $300 \mathrm{~s}$ 

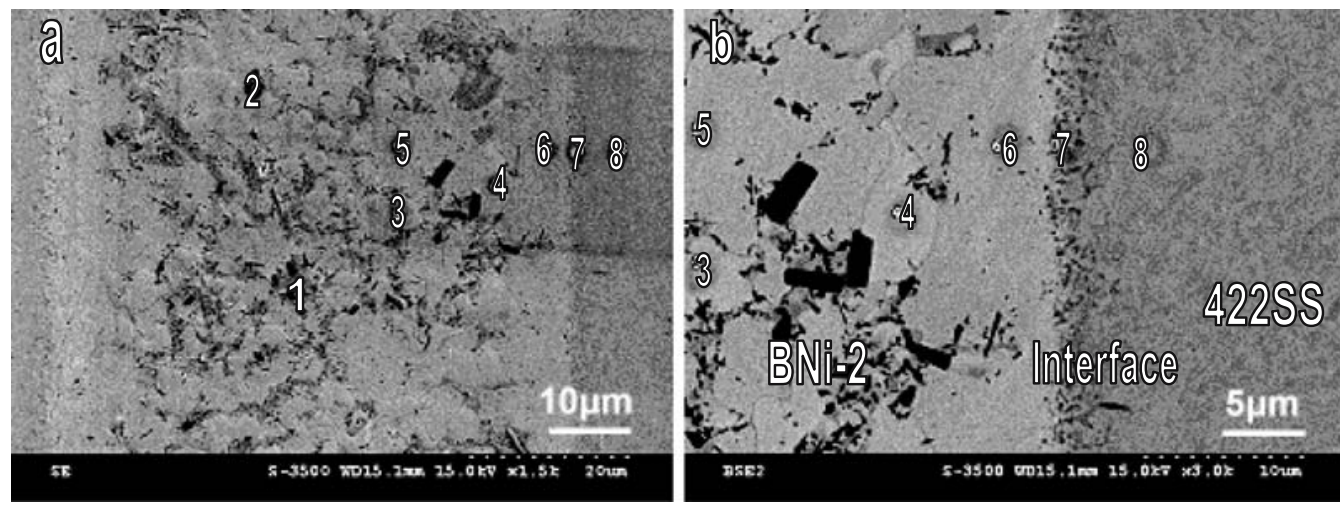

\begin{tabular}{ccccccccccc}
\hline at\% & $\mathrm{B}$ & $\mathrm{C}$ & $\mathrm{Si}$ & $\mathrm{Cr}$ & $\mathrm{Fe}$ & $\mathrm{Ni}$ & $\mathrm{V}$ & $\mathrm{Mn}$ & $\mathrm{Mo}$ & $\mathrm{W}$ \\
\hline 1 & 34.8 & 2.1 & 1.4 & 52.7 & 0.7 & 8.0 & 0.0 & 0.1 & 0.1 & 0.0 \\
2 & 35.7 & 2.5 & 0.1 & 58.5 & 0.6 & 2.4 & 0.0 & 0.1 & 0.1 & 0.0 \\
3 & 12.2 & 2.2 & 0.0 & 4.3 & 2.9 & 78.3 & 0.0 & 0.0 & 0.0 & 0.0 \\
4 & 15.1 & 2.3 & 0.0 & 4.1 & 3.1 & 75.3 & 0.0 & 0.0 & 0.0 & 0.0 \\
5 & 0.1 & 2.1 & 7.1 & 7.7 & 5.8 & 77.1 & 0.0 & 0.0 & 0.0 & 0.0 \\
6 & 0.6 & 2.2 & 8.4 & 6.4 & 7.6 & 74.7 & 0.1 & 0.0 & 0.0 & 0.0 \\
7 & 5.0 & 1.7 & 1.0 & 13.3 & 59.5 & 18.2 & 0.2 & 0.4 & 0.4 & 0.2 \\
8 & 0.0 & 2.2 & 0.7 & 12.2 & 82.5 & 0.8 & 0.1 & 0.8 & 0.5 & 0.2 \\
\hline
\end{tabular}

Fig. 3 The SEM (a) SEI, (b) BEI and EPMA chemical analysis results of the infrared brazed specimen at $1050{ }^{\circ} \mathrm{C}$ for $60 \mathrm{~s}$

$900{ }^{\circ} \mathrm{C}$ for 24 and $120 \mathrm{~h}$ in order to evaluate the microstructural evolution of the brazed joint.

A low speed diamond saw cut the brazed specimen, and the sample was subsequently performed a standard metallographic procedure prior to further inspection. The etching solution used in the experiment was $50 \%$ acetic acid and $50 \%$ nitric acid. The cross section of the brazed specimens was observed using a Hitachi $3500 \mathrm{H}$ scanning electron microscope (SEM) with an accelerating voltage of $15 \mathrm{kV}$. Quantitative chemical analysis was performed using a JEOL JXL-8800M electron probe microanalyzer (EPMA) with the spot size of $1 \mu \mathrm{m}$. The shear test was performed to evaluate the bonding strength of the brazed specimen. The brazed sample was compressed by a Shimadzu AG-10 universal testing machine with a constant speed of $0.25 \mathrm{~mm} / \mathrm{min}$. Accordingly, the fractured surface after shear test was examined by an SEM.

\section{Results and discussion}

Figure 1 shows the wetting angle measurements of BNi-2 braze alloy on 422SS for 1025, 1050, 1075 and $1100{ }^{\circ} \mathrm{C}$, respectively. The solidus and liquidus temperatures of the $\mathrm{BNi}-2$ braze alloy are $970{ }^{\circ} \mathrm{C}$ and $1000{ }^{\circ} \mathrm{C}$, respectively. It is expected that heating the braze alloy above $1000{ }^{\circ} \mathrm{C}$ results in complete melting of the braze alloy. However, the molten braze cannot effectively wet the $422 \mathrm{SS}$ at $1025^{\circ} \mathrm{C}$. Increasing the temperature above $1050{ }^{\circ} \mathrm{C}$, the $422 \mathrm{SS}$ is completely wetted by the molten braze in $600 \mathrm{~s}$. The wettability of $\mathrm{BNi}-2$ braze on the $422 \mathrm{SS}$ substrate is superior to that of BNi-3 braze alloy [13]. As described earlier, the major difference in chemical composition of these nickel base braze alloys is $7 \mathrm{wt} \% \mathrm{Cr}$ addition in the BNi-2 alloy. The addition of $\mathrm{Cr}$ into the nickel base braze alloy is beneficial to its wetting ability on the 422SS substrate. Based on the wetting angle test result, it is preferred that brazing $422 \mathrm{SS}$ using the $\mathrm{BNi}-2$ braze alloy be performed above $1025^{\circ} \mathrm{C}$.

Figure 2 shows the SEM back-scattered electron images (BEIs) of the infrared brazed specimens at $1050{ }^{\circ} \mathrm{C}$ for 60,180 and $300 \mathrm{~s}$, respectively. The backscattered electron image does not provide topographic contrast, but primarily shows the distribution of elements in the joint $[12,18,19]$. There are at least two phases, the matrix and angular black phases, in the infrared brazed joint. There is no continuous reaction layer between the braze and 422SS, but a reaction zone at the interface between the braze and 422SS is observed as displayed in Fig. 2. Additionally, the thickness of reaction zone is increased with increasing the brazing time as demonstrated in the figure. For example, the reaction zone is not obvious for the infrared brazed specimen with $60 \mathrm{~s}$ (Fig. 2a). In contrast, the thickness of interfacial reaction zone is approximately $10 \mu \mathrm{m}$ for the sample with $300 \mathrm{~s}$ infrared brazing (Fig. 2c). 
Fig. 4 The liquidus projection of $\mathrm{B}-\mathrm{Cr}-\mathrm{Ni}$ ternary alloy phase diagram and its reaction scheme [20]

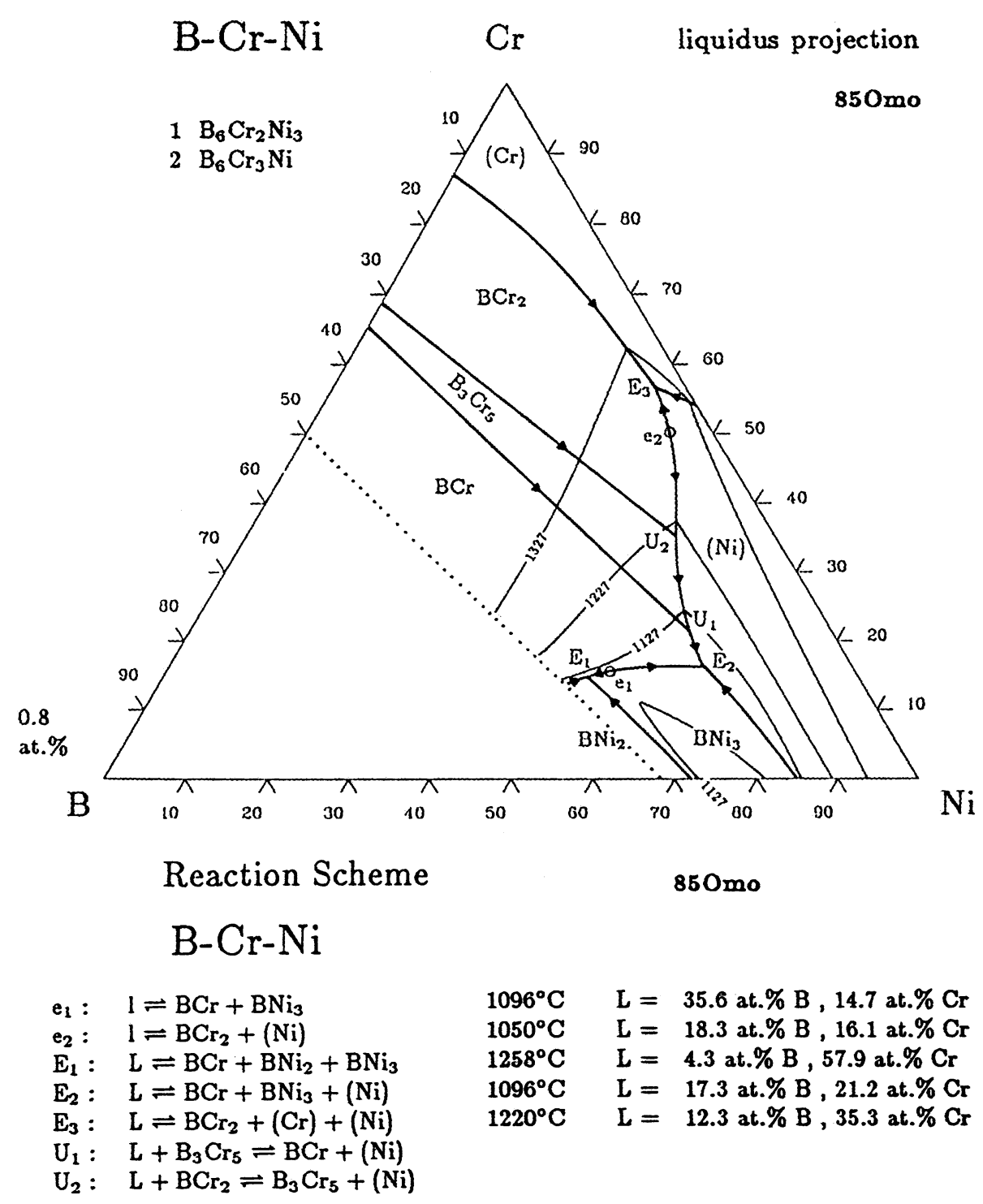

Figure 3 displays both the SEM images and EPMA chemical analysis results of the infrared brazed specimen at $1050^{\circ} \mathrm{C}$ for $60 \mathrm{~s}$. Based on the EPMA analysis results, chromium boride, nickel boride and the Ni-rich phases are observed in the braze as marked by points 1-6 (Fig. 3). The existence of chromium boride is consistent with the previous study of infrared brazing 403SS with the BNi-2 braze alloy [12]. A ternary alloy phase diagrams is cited here in order to unveil the microstructural evolution in the infrared brazed joint. Because the chemical composition of the $\mathrm{BNi}-2$ braze alloy in atomic percent is $6.6 \mathrm{Cr}, 14.1 \mathrm{~B}, 7.9 \mathrm{Si}, 2.6 \mathrm{Fe}$ and $\mathrm{Ni}$ balance, the $\mathrm{B}-\mathrm{Cr}-\mathrm{Ni}$ ternary alloy phase diagram is chosen for the study. Figure 4 displays the liquidus projection of the $\mathrm{B}-\mathrm{Cr}-\mathrm{Ni}$ ternary alloy phase diagram in atomic percent, and some important invariant reactions are also included in the figure [12,
20]. Based on the Fig. 4, the chemical composition of the molten braze is close to $\mathrm{E}_{2}$, and the ternary eutectic temperature at $\mathrm{E}_{2}$ in $\mathrm{B}-\mathrm{Cr}-\mathrm{Ni}$ phase diagram at $1050{ }^{\circ} \mathrm{C}$ is listed below $[12,20]$ :

$$
\mathrm{L} \leftrightarrow \mathrm{BCr}+\mathrm{BNi}_{3}+(\mathrm{Ni})
$$

The chemical composition of the liquid (L) in atomic percent is $18.3 \mathrm{~B}, 16.1 \mathrm{Cr}$ and $65.6 \mathrm{Ni}$. Three eutectic phases, $\mathrm{BCr}, \mathrm{BNi}_{3}$ and the $\mathrm{Ni}$-rich phase, are formed during the eutectic solidification. Accordingly, chromium boride, nickel boride and the Ni-rich phases are observed in the experiment as illustrated in Fig. 3. Additionally, the interfacial reaction is not prominent due to the rapid thermal cycle of infrared brazing. It is also noted that the braze alloy contains Fe dissolved from the 422SS substrate. The dissolution of 422SS 
Fig. 5 The SEM BEIs of furnace brazed specimens at (a) $1050{ }^{\circ} \mathrm{C} \times 600 \mathrm{~s}$, (b) $1050{ }^{\circ} \mathrm{C} \times 1800 \mathrm{~s},(\mathbf{c})$ $1075^{\circ} \mathrm{C} \times 600 \mathrm{~s},(\mathbf{d})$ $1075^{\circ} \mathrm{C} \times 1800 \mathrm{~s},(\mathbf{e})$ $1100{ }^{\circ} \mathrm{C} \times 600 \mathrm{~s}$ and $(\mathbf{f})$ $1100{ }^{\circ} \mathrm{C} \times 1800 \mathrm{~s}$
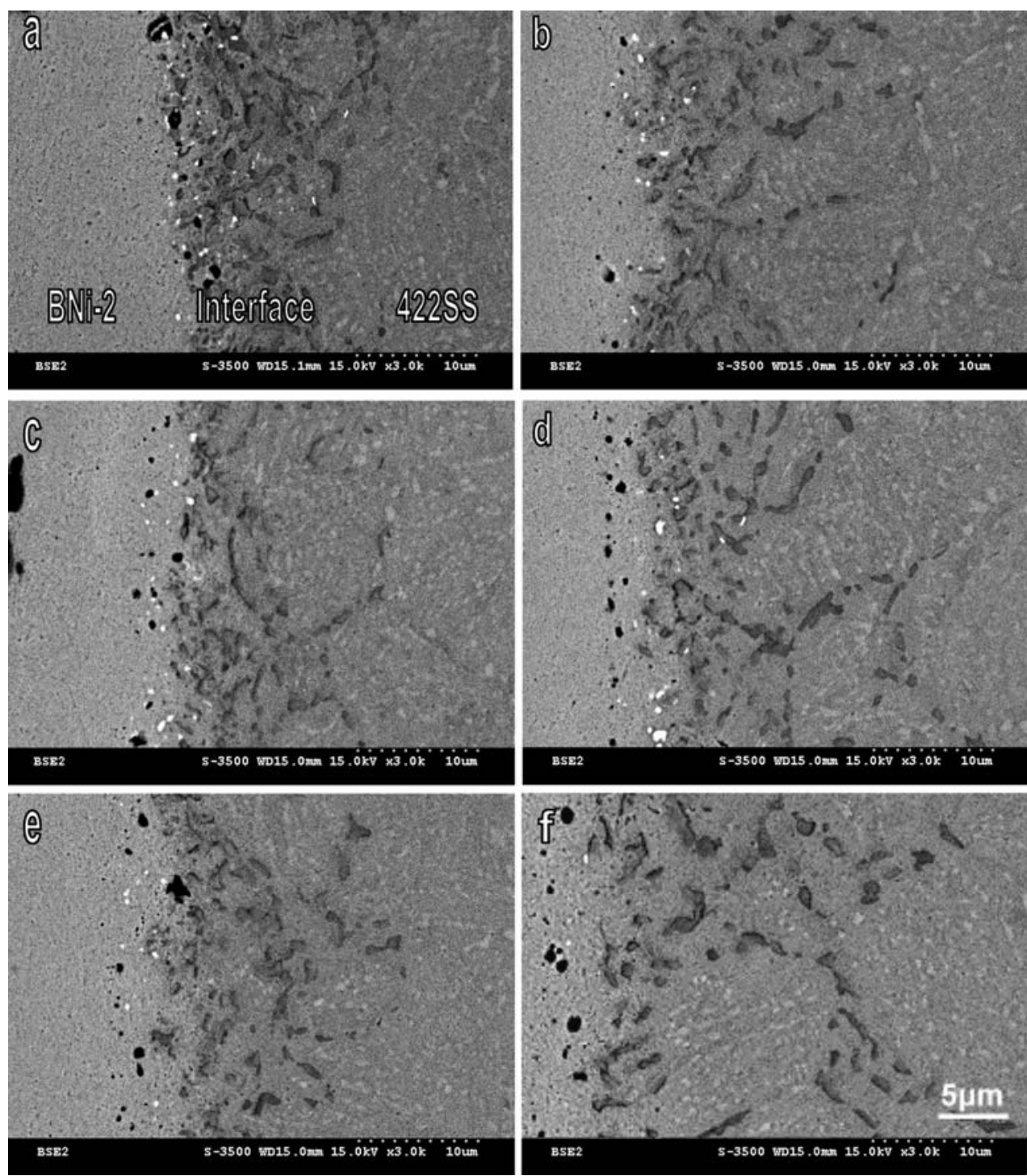

substrate into the molten braze may result in isothermal solidification of the molten braze during infrared brazing.

Figure 5 shows SEM BEIs of furnace-brazed specimens at various brazing conditions. Compared with the infrared brazed specimen, the interfacial reaction zone of the furnace-brazed specimen is greatly increased with increasing brazing temperature and/or time. Similar to the aforementioned result, there is no continuous reaction layer at the interface between the braze and 422SS. However, there are porosities in the braze close to the interface as illustrated in Fig. 5 . These porosities are called Kirkendall porosities, and they are caused by nonsymmetrical interdiffusion between the braze and 422SS substrate [11-13]. The $\mathrm{B}$ atoms diffuse much faster than $\mathrm{Fe}$ and $\mathrm{Cr}$ atoms. Boron can readily diffuse into $422 \mathrm{SS}$ substrate, but the diffusion rates of $\mathrm{Fe}$ and $\mathrm{Cr}$ atoms from the 422SS into the braze are much slower. Therefore, some Kirkendall voids with the size below 1 micron in the braze close to the interface between $\mathrm{BNi}-2$ and $422 \mathrm{SS}$ are observed as shown in Fig. 5. Because the Kirkendall effect is a diffusion-controlled phenomenon, it is highly temperature and time dependent. It is expected that the size of Kirkendall porosity is increased with increasing the brazing temperature and/or time [13].

Figure 6 shows the SEM images and EPMA chemical analyses of various phases in the furnace brazed specimen at $1050{ }^{\circ} \mathrm{C}$ for $600 \mathrm{~s}$. Based on the EPMA analyses, $\mathrm{BCr}$ (marked by 1 and 2), Ni-rich matrix (marked by 3 and 4), and interfacial precipitates (marked by 6 ) are observed in the experiment. The chemical composition of the interfacial precipitates is mainly comprised of $\mathrm{Fe}, \mathrm{Cr}, \mathrm{B}$ and $\mathrm{Ni}$. However, the 

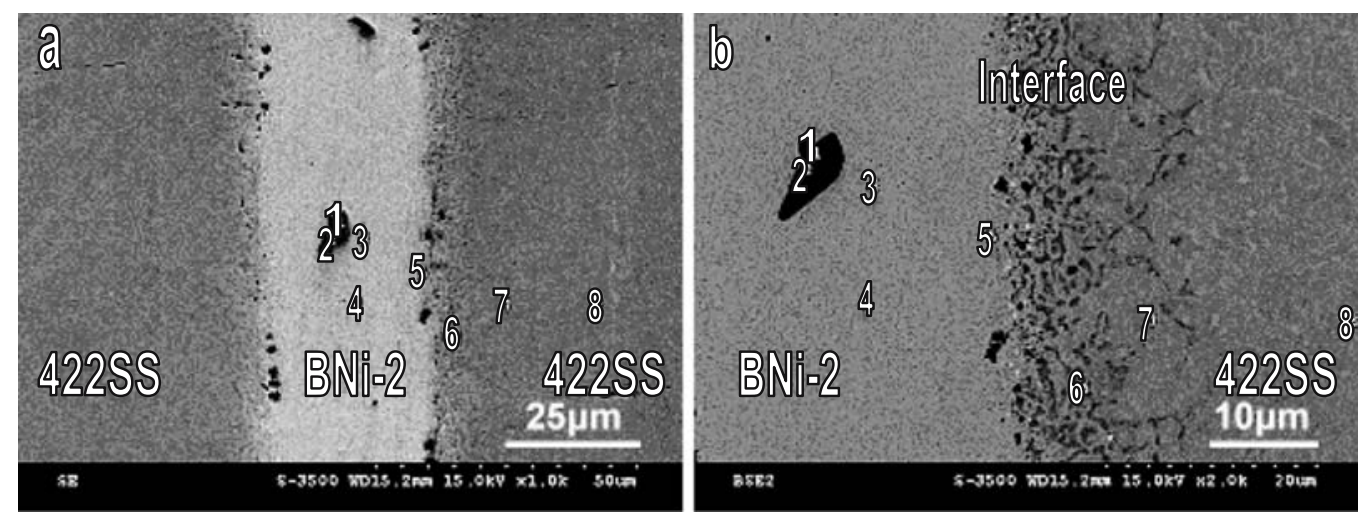

\begin{tabular}{ccccccccccc}
\hline at\% & $\mathrm{B}$ & $\mathrm{C}$ & $\mathrm{Si}$ & $\mathrm{Cr}$ & $\mathrm{Fe}$ & $\mathrm{Ni}$ & $\mathrm{V}$ & $\mathrm{Mn}$ & $\mathrm{Mo}$ & $\mathrm{W}$ \\
\hline 1 & 45.1 & 2.6 & 0.0 & 50.3 & 0.6 & 1.1 & 0.0 & 0.1 & 0.1 & 0.0 \\
2 & 42.1 & 7.3 & 0.1 & 48.5 & 0.6 & 1.2 & 0.0 & 0.1 & 0.1 & 0.0 \\
3 & 0.0 & 4.4 & 7.9 & 8.1 & 7.9 & 71.4 & 0.0 & 0.2 & 0.0 & 0.0 \\
4 & 0.0 & 2.9 & 8.0 & 7.5 & 7.6 & 73.9 & 0.0 & 0.1 & 0.0 & 0.0 \\
5 & 0.0 & 2.5 & 4.4 & 6.3 & 28.6 & 57.9 & 0.0 & 0.2 & 0.1 & 0.0 \\
6 & 5.4 & 2.0 & 0.7 & 10.0 & 73.2 & 7.8 & 0.1 & 0.5 & 0.3 & 0.1 \\
7 & 1.1 & 4.1 & 0.5 & 13.9 & 78.3 & 0.7 & 0.0 & 0.7 & 0.5 & 0.3 \\
8 & 0.0 & 2.5 & 0.6 & 12.4 & 82.5 & 0.7 & 0.1 & 0.7 & 0.3 & 0.1 \\
\hline
\end{tabular}

Fig. 6 The SEM (a) SEI, (b) BEI and EPMA chemical analysis results of the furnace brazed specimen at $1050{ }^{\circ} \mathrm{C}$ for $600 \mathrm{~s}$

minimum spot size of the EPMA chemical analysis is approximately $1 \mu \mathrm{m}$. The chemical composition of the interfacial precipitates in the reaction zone cannot be analyzed accurately due to its size below $1 \mu \mathrm{m}$. The amount of $\mathrm{BCr}$ phase in the braze is greatly decreased, and the braze is mainly comprised of the Ni-rich matrix alloyed with $\mathrm{Fe}, \mathrm{Cr}$ and $\mathrm{Si}$.
Figure 7 shows the SEM BEIs and EPMA chemical analysis results of the furnace-brazed specimen at $1050{ }^{\circ} \mathrm{C}$ for $1800 \mathrm{~s}$. The $\mathrm{BCr}$ phase in the braze is disappeared, and the braze mainly consists of the $\mathrm{Ni}$ rich matrix alloyed with $\mathrm{Fe}, \mathrm{Cr}$ and $\mathrm{Si}$ as marked by 1 and 2 in Fig. 7. Additionally, the interfacial precipitates are coarsened, and its chemical composition is
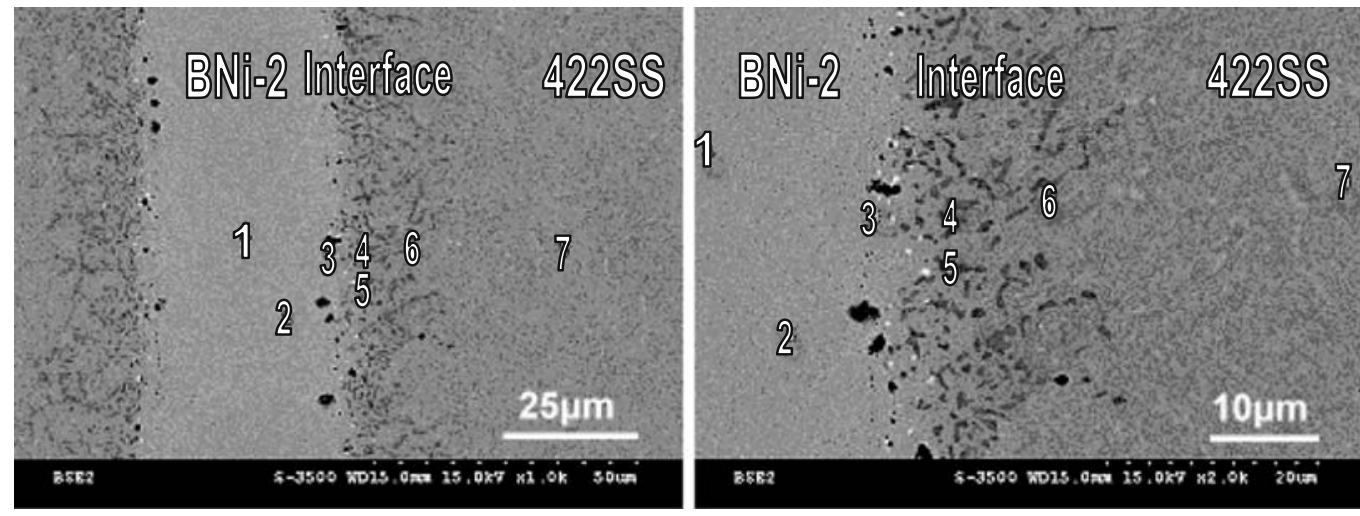

\begin{tabular}{ccccccccccc}
\hline at\% & $\mathrm{B}$ & $\mathrm{C}$ & $\mathrm{Si}$ & $\mathrm{Cr}$ & $\mathrm{Fe}$ & $\mathrm{Ni}$ & $\mathrm{V}$ & $\mathrm{Mn}$ & $\mathrm{Mo}$ & $\mathrm{W}$ \\
\hline 1 & 0.0 & 1.5 & 8.1 & 8.2 & 10.5 & 71.6 & 0.0 & 0.2 & 0.0 & 0.0 \\
2 & 0.9 & 1.0 & 7.0 & 7.8 & 17.0 & 66.1 & 0.0 & 0.2 & 0.0 & 0.0 \\
3 & 0.0 & 0.9 & 2.8 & 7.9 & 41.5 & 46.4 & 0.0 & 0.2 & 0.2 & 0.1 \\
4 & 12.9 & 1.4 & 0.2 & 22.3 & 58.3 & 3.6 & 0.1 & 0.5 & 0.3 & 0.3 \\
5 & 13.9 & 1.2 & 0.4 & 17.0 & 60.6 & 5.9 & 0.0 & 0.4 & 0.4 & 0.3 \\
6 & 0.9 & 2.8 & 0.6 & 10.7 & 83.1 & 0.7 & 0.0 & 0.6 & 0.4 & 0.0 \\
7 & 0.0 & 1.4 & 0.6 & 11.2 & 85.1 & 0.7 & 0.0 & 0.7 & 0.3 & 0.0 \\
\hline
\end{tabular}

Fig. 7 The SEM BEIs and EPMA chemical analysis results of the furnace brazed specimen at $1050{ }^{\circ} \mathrm{C}$ for $1800 \mathrm{~s}$ 

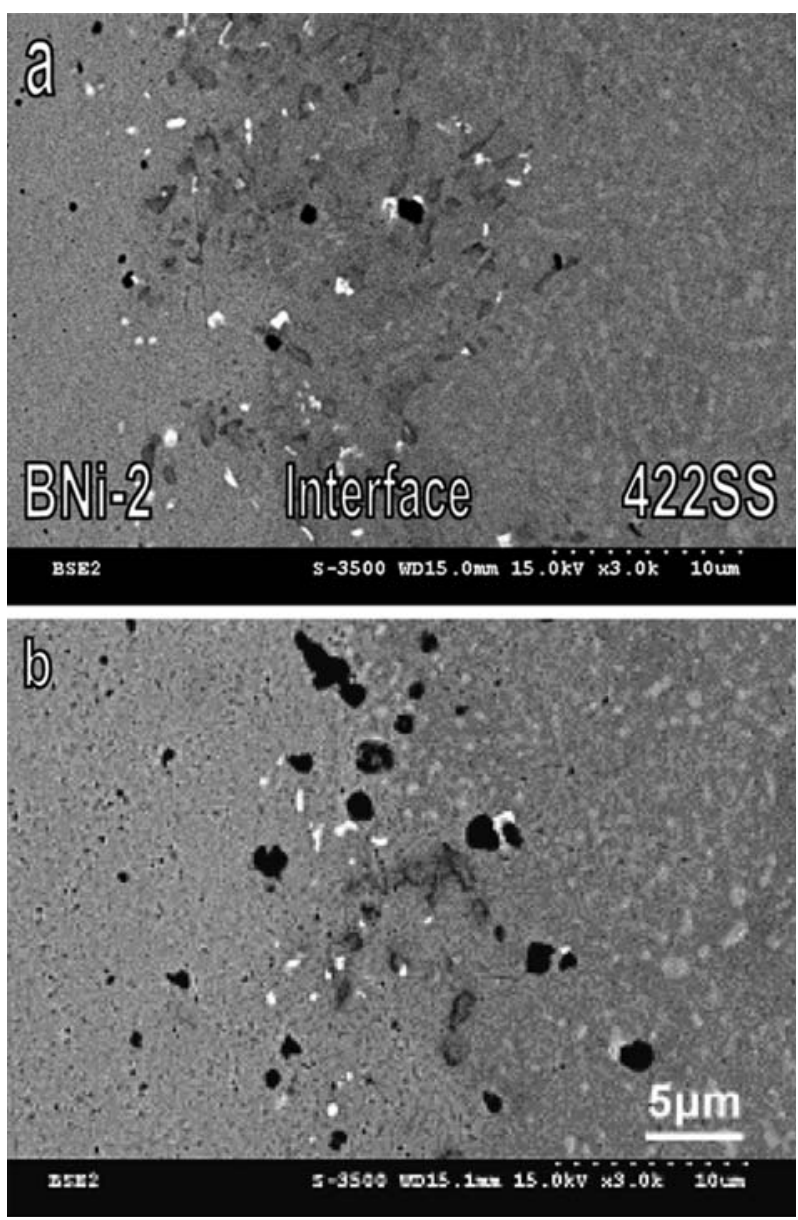

Fig. 8 The SEM images of the furnace brazed specimen at $1050{ }^{\circ} \mathrm{C} \times 600 \mathrm{~s}$ and subsequently heat-treated at $900{ }^{\circ} \mathrm{C}$ for $(\mathbf{a})$ 24 and (b) $120 \mathrm{~h}$

primarily comprised of $\mathrm{Fe}, \mathrm{Cr}$ and $\mathrm{B}$ as marked by 4 and 5 in the figure. It is reasonable to conclude that the formation of interfacial $\mathrm{Fe}-\mathrm{Cr}-\mathrm{B}$ precipitates results in depletion of the boron content from the braze. The amount of $\mathrm{BCr}$ phase in the braze is decreased with increasing brazing temperature and/or time. Similar to the aforementioned result, some Kirkendall porosities are also observed in the braze close to the interface as shown in Fig. 7.

The furnace-brazed specimens were subsequently homogenized at $900{ }^{\circ} \mathrm{C}$ for 24 and $120 \mathrm{~h}$ in order to study the microstructural evolution of the furnace brazed specimen. Figure 8 shows the SEM BEIs of furnace brazed specimens at $1050{ }^{\circ} \mathrm{C}$ for $600 \mathrm{~s}$ and subsequently heat-treated at $900{ }^{\circ} \mathrm{C}$ for 24 and $120 \mathrm{~h}$, respectively. It is obvious that the longer homogenization time results in enhanced Kirkendall effect. Consequently, larger voids are observed at the interface between the braze and 422SS as illustrated in Fig. $8 \mathrm{~b}$. The homogenization treatment of the furnace brazed specimen results in growth of both the interfacial reaction zone and Kirkendall porosity.

Table I shows the shear strength of brazed 422SS/ $\mathrm{BNi}-2 / 422 \mathrm{SS}$ specimens for various brazing conditions. Averaged shear strengths of brazed joints are varied from 306 to $481 \mathrm{MPa}$. The infrared brazed specimen at $1050{ }^{\circ} \mathrm{C}$ for $60 \mathrm{~s}$ demonstrates the highest averaged shear strength up to $481 \mathrm{MPa}$. Increasing brazing temperature and/or time result in decreasing the shear strength of the brazed joint. Therefore, the furnace brazed specimen at $1100{ }^{\circ} \mathrm{C}$ for $1800 \mathrm{~s}$ demonstrates the lowest averaged shear strength among all brazed joints.

Figure 9 shows cross sectional SEM BEIs of 422SS/ $\mathrm{BNi}-2 / 422 \mathrm{SS}$ specimens after shear test for various brazing conditions. It is clear that all brazed specimens are fractured at the braze alloy. The interfacial reaction zone has little effect on the shear strength of the brazed specimen. Figure 10 shows fractographs of brazed specimens with different brazing conditions after shear tests. It demonstrates that fractographs of furnace-brazed specimens mainly consist of ductile dimple fracture (Fig. 10b, c). In contrast, the fractograph of the infrared brazed specimen is mainly comprised of quasi-cleavage fracture (Fig. 10a). As described earlier, the infrared brazed specimen contains the brittle chromium boride phase. The
Table 1 The shear strength of brazed 422SS/BNi-2/422SS specimens

\begin{tabular}{lllll}
\hline Furnace type & Temperature & Time & Shear stress & Averaged shear stress \\
\hline Infrared & $1050^{\circ} \mathrm{C}$ & $60 \mathrm{~s}$ & $475 \mathrm{MPa}$ & $481 \mathrm{MPa}$ \\
Infrared & $1050^{\circ} \mathrm{C}$ & $60 \mathrm{~s}$ & $486 \mathrm{MPa}$ & \\
Traditional & $1050^{\circ} \mathrm{C}$ & $600 \mathrm{~s}$ & $411 \mathrm{MPa}$ & $412 \mathrm{MPa}$ \\
Traditional & $1050^{\circ} \mathrm{C}$ & $600 \mathrm{~s}$ & $413 \mathrm{MPa}$ & \\
Traditional & $1050^{\circ} \mathrm{C}$ & $1800 \mathrm{~s}$ & $365 \mathrm{MPa}$ & $357 \mathrm{MPa}$ \\
Traditional & $1050^{\circ} \mathrm{C}$ & $1800 \mathrm{~s}$ & $349 \mathrm{MPa}$ & \\
Traditional & $1100^{\circ} \mathrm{C}$ & $600 \mathrm{~s}$ & $335 \mathrm{MPa}$ & $339 \mathrm{MPa}$ \\
Traditional & $1100^{\circ} \mathrm{C}$ & $600 \mathrm{~s}$ & $343 \mathrm{MPa}$ & \\
Traditional & $1100^{\circ} \mathrm{C}$ & $1800 \mathrm{~s}$ & $307 \mathrm{MPa}$ & $306 \mathrm{MPa}$ \\
Traditional & $1100^{\circ} \mathrm{C}$ & $1800 \mathrm{~s}$ & $304 \mathrm{MPa}$ & \\
\hline
\end{tabular}



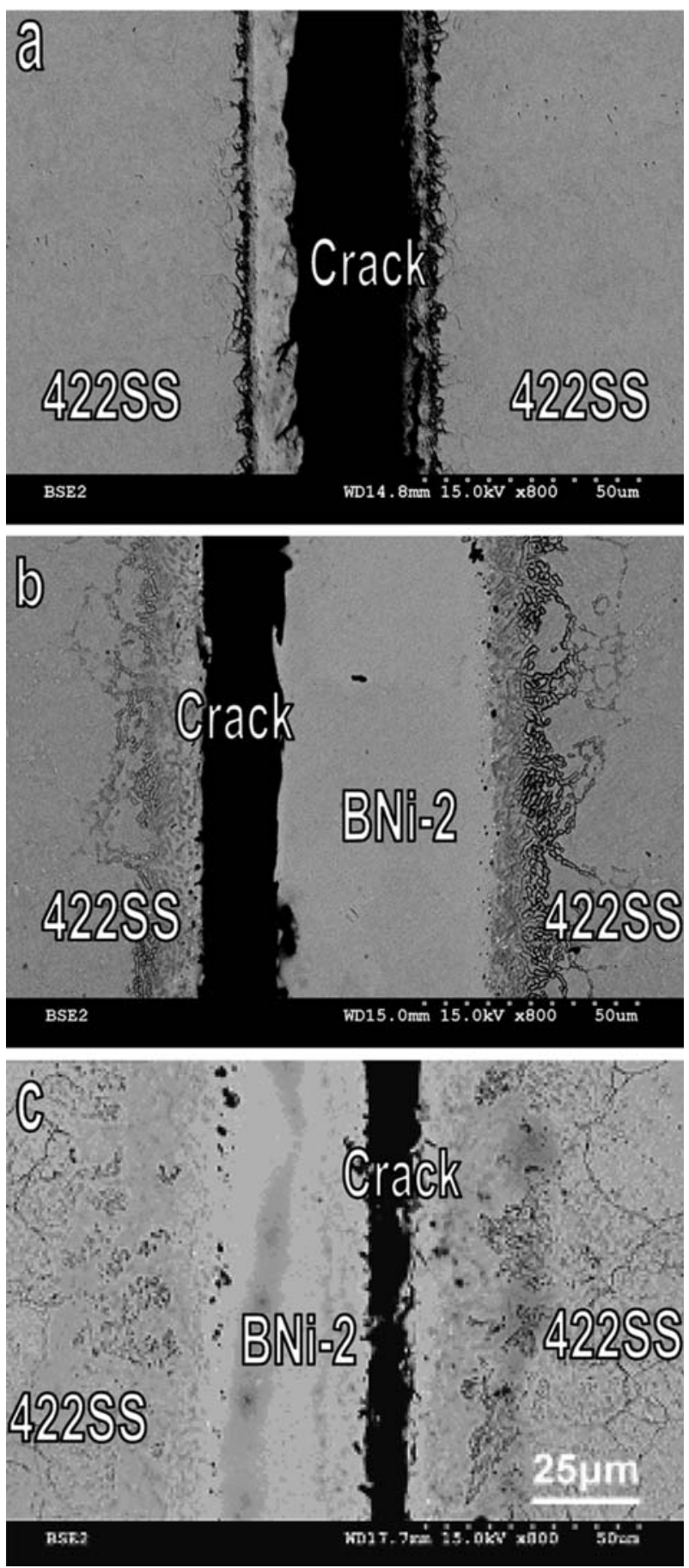

Fig. 9 Cross sectional SEM BEIs of the 422SS/BNi-2/422SS joint after shear test: (a) $1050{ }^{\circ} \mathrm{C} \times 60 \mathrm{~s}$ (infrared brazing), (b) $1050{ }^{\circ} \mathrm{C} \times 1800 \mathrm{~s}$ (furnace brazing) and (c) $1100{ }^{\circ} \mathrm{C} \times 1800 \mathrm{~s}$ (furnace brazing)

amount of chromium boride phase is greatly decreased as the brazing temperature and/or time increased. The boron content in the braze is depleted from the braze alloy, and the ductile Ni-rich phase dominates the shear strength of the brazed joint for the furnace
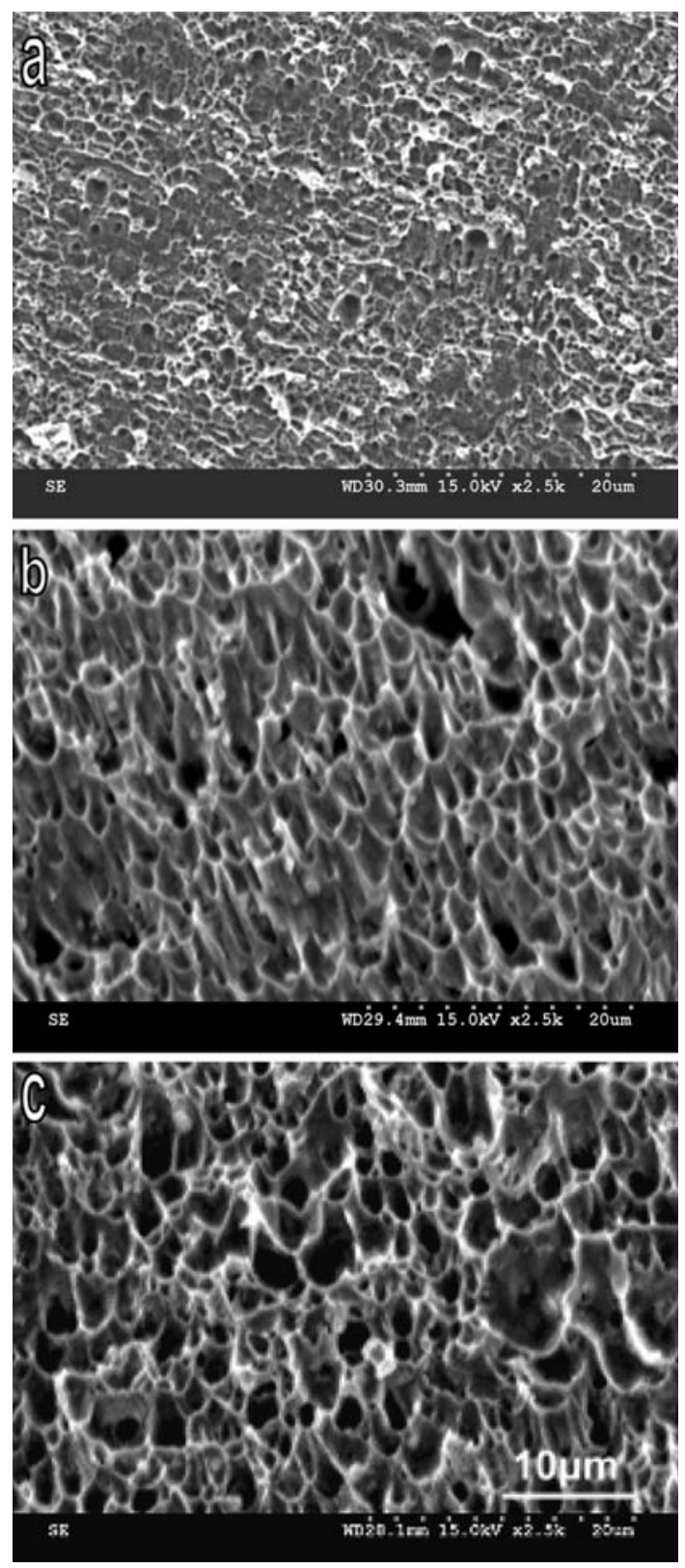

Fig. 10 The SEM fractographs of brazed specimens after shear test, (a) $1050{ }^{\circ} \mathrm{C} \times 60 \mathrm{~s}$ (infrared brazing), (b) $1050{ }^{\circ} \mathrm{C} \times 1800 \mathrm{~s}$ (furnace brazing) and (c) $1100{ }^{\circ} \mathrm{C} \times 1800 \mathrm{~s}$ (furnace brazing)

brazed specimen. Therefore, ductile dimple fracture is usually observed for the furnace-brazed specimen.

\section{Conclusion}

The study of brazing 422SS using the BNi-2 braze alloy as the filler metal has been evaluated. Both the traditional furnace brazing and infrared brazing are included in the experiment. Based on the wetting angle measurements, it is preferred that brazing 422SS using 
the BNi-2 alloy is performed above $1025^{\circ} \mathrm{C}$. The brazed joint is primarily comprised of the $\mathrm{Ni}$-rich phase and chromium boride. As the brazing temperature increasing, boron atoms readily diffuse into the 422SS substrate, and form $\mathrm{B}-\mathrm{Cr}-\mathrm{Fe}$ precipitates at the interfacial reaction zone. The formation of interfacial B$\mathrm{Cr}-\mathrm{Fe}$ precipitates results in depletion of the boron content from the braze alloy. The amount of $\mathrm{BCr}$ phase in the braze is decreased with increasing brazing temperature and/or time. Additionally, some Kirkendall porosities are observed in the braze close to the interface due to nonsymmetrical interdiffusion between the braze and 422SS substrate. The size of Kirkendall porosity is increased with increasing the brazing temperature and/or time. Averaged shear strengths of brazed joints are varied from 306 to $481 \mathrm{MPa}$. The infrared brazed specimen demonstrates the highest averaged shear strength among all specimens. Increasing brazing temperature and/or time result in decreasing the averaged shear strength of the brazed joint. All brazed specimens are fractured at the braze alloy itself during the shear test. Fractographs of furnace brazed specimens show that the fractured surface mainly consists of ductile dimple fracture. In contrast, the fractograph of infrared brazed specimen exhibits the quasi-cleavage fracture due to the existence of many brittle chromium borides in the braze alloy.

Acknowledgements The authors gratefully acknowledge the financial support of this research by the National Science Council (NSC), Republic of China under grant numbers, NSC 90-2216-E259-003 and NSC 91-2216-E-259-002. EPMA analysis by Ms.
Shu-Yueh Tsai in NSC Instrument Center, National Tsing Hua University, Hsinchu, Taiwan, is also gratefully appreciated.

\section{References}

1. Balmforth MC, Lippold JC (1998) Welding J 77:1s

2. Corbit RB, French SM (1997) Welding J 76:51

3. Armstrong D (1993) Welding World 31:426

4. Lee MK (1998) J Nucl Mater 254:42

5. Chandler H (1995) Heat Treater's Guide: practices and procedures for irons and steels. ASM International, Metals Park, Ohio, p 763

6. Davis JR (1994). ASM specialty handbook: stainless steels. ASM International, Metals Park, Ohio

7. Han HY, Sun Z (1994) Inter J Pressure Vessels Piping 60:59

8. Ginn BJ, Gooch TG (1998) Welding J 77:341s

9. Olson DL, Siewert TA, Liu S, Edwards GR (1993) ASM handbook Volume 6 welding, brazing, and soldering”. ASM International, Metals Park, Ohio

10. Schwartz M (1995) Brazing: for the engineering technologist". Chapman \& Hall, New York

11. Humpston G, Jacobson DM (1993) Principles of soldering and brazing". ASM International, Metals Park, Ohio, p 71

12. Shiue RK, Wu SK, Hung CM (2002) Metall Mater Trans 33A: 1765

13. Ou CL, Shiue RK (2003) J Mater Sci 38:2337

14. Shiue RK, Wu SK, Chen SY (2003) Acta Meter 51:1991

15. Yang TY, Wu SK, Shiue RK (2001) Intermetallics 9:341

16. Lee YL, Shiue RK, Wu SK (2003) Intermetallics 11:187

17. Shiue RK, Wu SK, O JM, Wang JY (2000) Metall Mater Trans 31A:2527

18. Liu CC, Ou CL, Shiue RK (2002) J Mater Sci 37:2225

19. Lee RE (1993) Scanning electron microscopy and X-ray microanalysis. Prentice Hall, New York, p 130

20. Villars P, Prince A, Okamoto H (1995) Handbook of ternary alloy phase diagrams. ASM International, Metals Park, Ohio, p 5508 